\title{
Assessment of the Impact of Fiscal Policy Operations on Stock Price Performance: Empirical Evidence from Nigeria
}

\author{
Onyemachi Maxwell Ogbulu ${ }^{1}$, Lezaasi Lenee Torbira ${ }^{2} \&$ Chizoba Lynda Umezinwa $^{3}$ \\ ${ }^{1}$ Dept. of Banking and Finance, Abia State University, Uturu, Nigeria \\ ${ }^{2}$ Dept. of Finance and Banking, University of Port Harcourt, Port Harcourt, Nigeria \\ ${ }^{3}$ Dept. of Banking and Finance, Federal Polytechnic, Oko, Anambra State, Nigeria \\ Correspondence: Onyemachi Maxwell Ogbulu, Dept. of Banking and Finance, Abia State University, Uturu, Nigeria. \\ Tel: 234-80-3340-1924.E-mail: hrhogbulu@yahoo.com,maxwellogbulu54@gmail.com
}

Received: March 23, 2015

Accepted: April 13, 2015

Online Published: April 17, 2015

doi:10.5430/ijfr.v6n2p190

URL: http://dx.doi.org/10.5430/ijfr.v6n2p190

\begin{abstract}
This paper examines the relationship between Government fiscal policy measures and stock prices in Nigeria during the period 1985 - 2012. Employing OLS, co-integration, error correction mechanism (ECM), Granger Causality and impulse response and variance decomposition techniques on fiscal policy - stock prices model patterned after a multivariate regression, the study found a significant and negative impact of Public expenditure on stock prices, while Government Domestic Debt Outstanding exerts a significant and positive influence on stock prices. The study also reports a significant and positive relationship between Non-Oil Revenue and stock prices while the two-period and three-period lagged values of broad money supply have significant relationship with stock prices. The Granger causality tests reveal that Stock prices lead changes in Public Expenditure, Domestic Debt and Money Supply respectively while Non-Oil Revenue leads changes in stock prices. The results of both the IRF and VDC analysis reveal that own shocks represent the dominant source of variation in the forecast errors of the variables. The paper therefore recommends that appropriate fiscal policies should be designed and implemented on account of the significant and profound impact of fiscal policies on stock market prices.
\end{abstract}

Keywords: fiscal policy, stock prices, government expenditure, government revenue, ECM

\section{Introduction}

The controversy as to whether fiscal policy exerts any significant influence on stock market activities has been on the front burner of discourse among experts in behavioural finance. While some scholars argue that fiscal policy operations have no effect on stock market activities, others like Plosser (1982), Darrat (1988), McGrattan and Prescott (2001) as well as Afonso and Songa (2009) posit that fiscal actions could affect stock market activities through changes in the rate of interest, portfolio adjustment/revaluation, changes in investment as well as changes in aggregate demand in the economy thus affecting asset prices and the entire economy.

The Keynesian school opine that the analysis of the interactions between fiscal policy actions and interest rates suggest that stock market activities cannot be completely independent of fiscal policy shocks. Changes in fiscal instruments (like government spending, taxes and other revenue items) can change market interest rates instantaneously and force investors to revalue their asset (stock) holdings. As such, the value of investors' wealth (which includes equity holdings), derived by the summation of the discounted value of future cash flows could be affected by an easing or tightening of fiscal policy (Reilly and Norton, 1999).

Meek (1960), hypothesized that to encourage the growth or activities of capital markets the government should increase the availability of alternative sources of public finance, reduce tariffs in order to make the market more competitive and pursue economic stabilization policies. These policies, working together, could create an open competitive market that attracts entrepreneurs to invest in the capital market without fear of losing their investment due to unsound government fiscal policies. Tax and expenditure policies are examples of how the government attempt to control investment and indirectly the depth and breadth of capital market as well as stock prices.

In the literature of finance, fiscal policy action such as changes in government expenditure or increases in tax rates with government spending remaining unchanged, for instance, lowers after-tax expected returns on assets and hence 
prices since they discourage rational investors from further investing in the stock market. On the contrary, optimal fiscal policy mix, elevates investors' confidence and help stimulate their investment activities. Thus, government revenue and spending adjustments are expected to have profound effect on stock prices (Reilly and Norton, 1999; Levine, 1991).

Fiscal policy refers to the discretionary changes in the level, composition and timing of government expenditure and revenues. Fiscal policy deals with government expenditure (both recurrent and capital expenditure) and government taxation as well as other revenues aimed at influencing economic activities or achieving desired macroeconomic goals in a given economy. Government expenditure refers to the aggregate of a country's public sector spending in all aspects of its activities which could be for recurrent or capital purposes (Anyanwu, 1997).

Capital expenditure seems to portend some impact on stock market activities than recurrent expenditure. However, the expected effect of capital expenditure decisions on stock prices depends to a large extent on the market's assessment of the quality of its investment opportunities. For example, Desai, Wright and Chung (2003) studied investment opportunities and market reaction to capital expenditure decisions and opined that announcements of increases (decreases) in government capital spending positively (negatively) affect the stock prices of companies with valuable investment opportunities. For such firms, the market reacts favourably to increases in government capital budgets but negatively to decreases in capital budgets of government. On the contrary, for firms with poor investment opportunities, the prices of their stocks react negatively to increases in the capital budgets but positively to decrease in capital budgets.

Despite the fact that investigations of the linkage between fiscal policy and stock prices are well documented in finance literature for the developed and other developing countries, only a few body of research has attempted to thoroughly examine the time series property of fiscal policy actions and their influence on stock market prices in an emerging economy like Nigeria. This poor documentation of the empirical interaction between fiscal policy actions and stock market activities present a research challenge. It raises the question of the empirical validity of the theories that postulate that stock market activities do respond to government fiscal policy actions over time. It also calls for the re-examination of government policy actions directed at the financial markets and particularly the capital market with a view to finding out whether such policy actions have achieved their desired objectives in Nigeria.

\subsection{Objective of the Paper}

Financial economists, analysts and policy makers alike do attempt to predict and explain or fathom the nature of the behavioural relationship between fiscal policy adjustments and stock prices. Is the fluctuation in stock prices, in part, explained or induced by adjustments and variations in fiscal policies? In view of the above, the broad objective of this paper therefore, is to investigate the nature and extent of the relationship between government fiscal policies and stock prices in Nigeria as well as examine whether there is any granger causality relationship between fiscal policy measures and stock prices.

The remaining parts of the paper are organised as follows: section 2 dwells on review of empirical literature, section 3 discusses the methodology and data while empirical results and analysis are in section 4 . In section 5, we present summary and discussion of findings and section 6 contains the conclusion.

\section{Theoretical Issues and Review of Empirical Literature}

\subsection{Theoretical Issues}

The seeming ability of government spending to affect stock prices was suggested by Keynes. Known as the Traditional Keynesian theory, it proposes that expansionary fiscal policy (government spending) will create more income to economic units, increase the level of aggregate demand, raise the general price level, stimulate investment and have a more than one- for- one effect on the output level of the economy. Keynes also posits that removing government spending from the economy will reduce the level of aggregate demand and contract the economy thus affecting asset (stock) prices. However, the effect of the fiscal policy expansion depends on the degree of openness and the exchange rate regime of the economy (Hebous, 2013).

Wagner's Law of Increasing State Activities which is built on the recognition of the need by governments to provide and expand the share of public goods in investment, advocates that a rise in government expenditure could lead to an increase in the level of income, providing individuals with the ability to invest more in the capital market and raising the demand for stocks. This increase in stock demand could raise price and expand supply. This suggests that government expenditure has a functional relationship with stock prices (Laopodis, 2009). 
The Fundamentalist approach to security analysis posits that every security has an intrinsic value and that the intrinsic value is affected by economic conditions including government policies. Fiscal policies are government policies and stock prices are among the most volatile capital market indicators that are highly sensitive to economic condition/government policies. In the context of the transmission mechanism through the stock market, fiscal policy actions affect stock prices, which themselves are connected to the real sector of the economy through their influence on consumption and investment spending (Okafor, 1983).

\subsection{Past Empirical Studies}

Empirical submissions on the linkage between fiscal policy operations and stock market performance differ significantly among researchers. The opinion that some form of relationship exists between the variables is largely supported by finance literature. However, a review of existing studies shows that some reported findings are in conflict with the position of the reviewed theories. For instance, Laopodis (2006) examined the dynamic linkage between the federal government budget deficits and the stock market performance indicators for the period 1960 to 2004 in the USA. The empirical results suggest a violation of the reviewed theories and further analysis using federal government taxes and spending show a higher sensitivity of stock market indices to taxes relative to government spending.

In a two-country study, Razin (1987) used a stochastic general equilibrium model to address the issues concerning the effects of government tax and spending policies on private sector consumption, asset portfolios and stock market valuations. The key result of the study is that the consequencies of expected future policies and the characteristics of their international transmission depend critically on the precise variability of these policies across states of nature. That is, the effects of current policies on consumption, savings and stock market prices are shown to conform closely to the predictions of the corresponding certainty inter-temporal model.

Darrat (1988), focusing on whether current stock returns fully incorporate all past fiscal policy actions of government in Canada, using quarterly data for the period 1960 to 1984, and utilising the ordinary leased square (OLS) method, found that changes in fiscal policy stance play an important role in determining stock market returns. The study further revealed, after controlling for the effects of fiscal policy on the required return to capital, that there is empirical evidence indicating the presence of a significant lagged relationship between fiscal policy measures and current stock prices. As such, the study found conclusive evidence in support of the condition that fiscal policy influences stock prices.

In a related study investigating the nexus between fiscal policy shocks and movements in asset markets in the U.S, U.K, Germany and Italy using a VAR framework, Afonso and Sousa (2009) found that it is important to explicitly consider government debt dynamics when assessing the macroeconomic effects of fiscal policy on asset markets. Again, the results from the VAR analysis suggest that fiscal policy shocks exert minor influence on the asset markets of the U.S and Germany; fiscal policy shocks substantially increase the variability of stock prices in the U.K and government revenue shocks have apparently contributed to the increase in stock price volatility in Italy.

In addition, Ezirim, et al (2010) reported that public expenditure growth has been seen to significantly and positively precede persistent price increases in Kenya, United Kingdom and the United States of America but not in Nigeria. It was also found that price increases significantly affect public expenditure growth in Kenya and the United States of America.

Rad (2003) examined the effect on prices of government revenue and expenditure in Iran and employing the simultaneous equation system on quarterly data. The author found that growth in government budget deficits positively correlates with the persistent rise in asset prices during the period under study.

Fatas and Mihov (2001) considered a cholesky ordering in the identification of fiscal shocks. They reported that increase in government expenditure leads to growth in private investment that more than compensates for the fall in private consumption, a feature that goes against the predictions of the Real Business Cycle Model.

Plosser (1982) studied the effect of changes in government purchases and changes in public debt on Treasury bill rates in the United States of America and found that government spending significantly but negatively correlates with Treasury bill rates while government debt has weak correlation with interest rates. McGrettan and Prescott (2001) showed that the fall in effective tax rates led directly to the doubling in equity values as a share of GDP, as investors recognised the increased opportunity for investing, stimulating the demand for equities and raising equity/stock prices.

Leeper and Yun (2005) analysed fiscal theory adopting Slutsky-Hicks decomposition method and reported that revaluation effects arise whenever tax changes alter the value of outstanding nominal government liabilities by 
changing the price level. Under certain fiscal behaviour, the revaluation effects reflect the fiscal theory mechanism such that, when taxes change, two Laffer curves arise, suggesting that a tax increase can either lower or raise the price level and the revaluation effect can be positive or negative, depending on which side of the particular Laffer curve the economy resides.

Travares and Valkanov (2003) who investigated the effect of tax spending on quarterly market returns on stocks, government bonds and corporate bonds in the United States of America from 1960 to 2000 using co-integration, standard deviation and ordinary least squares techniques reported that a one standard deviation increase in the share of tax receipts has a statistically significant effect on stock returns by $4 \%$ and $9 \%$ at quarterly and yearly horizons respectively. The impact is also similar for stocks and bond returns. The result also indicated that government spending has positive and statistically significant impact on expected returns for bonds at short horizons. These imply that fiscal policy shocks account for about $3 \%$ to $4 \%$ of variation in excess stock returns and about $8 \%$ to $10 \%$ of the variation in excess bond returns. They posited that fiscal policy is an important source of return volatility and strongly suggest that fiscal policy shocks should be given serious consideration in asset pricing.

In a cross-country study, Lee (2007) investigated whether fiscal policy affects stock markets in Belgium, France, Germany, United Kingdom and the USA using Granger causality test, Vector Error Correction Model (VECM) and vector autoregressive estimates (VAR) techniques. The study employed quarterly data on stock prices, Federal budget deficits, money supply and industrial production from 1974-1998. Empirical results of the study revealed that the stock market in Belgium did not fully capture and reflect publicly available information on fiscal policy proxied by government budget deficits unlike in the other countries where fiscal policy significantly affected aggregate stock prices. The study also found out that the stock markets of all the five countries fully and accurately captured publicly available information on money supply.

In a related study, Afful and Asiedu (2013) examined the influence of fiscal policy and stock market activity on the lending-deposit rates spread in Sub-Saharan Africa using data from Botswana, Ghana, Mauritius and South Africa. The empirical findings showed that when pooled data were used, a positive and significant relationship exists between fiscal policy and the interest rate spread and stock market activity respectively. However, when examined separately, and except for South Africa, in all the others, stock market activity had no significant impact on interest rate spread.

The paper by Da, Warachta and Yun (2012) investigated whether counter cyclical government fiscal policies lower equity returns by smoothing consumption spending using annual data on government revenue, government expenditure, income and GSP for the US economy from 1965-2008. The results of the study indicate that consumption volatility and stock returns are lowered by counter-cyclical fiscal policies.

In yet another work, Hsing (2013) conducted a study to examine the potential impacts of fiscal and monetary policies on stock market performance in Poland. The author applied the GARCH model on quarterly data covering the period 1999.Q2 to 2012.Q4. Empirical findings of the study showed that Poland's stock market index is not affected by the ratio of government's deficit or debt to GDP and is negatively influenced by money market rate. The results further demonstrate that Poland's stock market index is positively associated with industrial production and negatively affected by nominal exchange rate and inflation rate respectively.

In sum, the above empirical review of literature with respect to the relationship between fiscal policy and stock market prices reveal that the controversy is far from settled. As demonstrated above, some studies report a positive and significant impact of fiscal policy measures on stock prices while other empirical works present a negative and significant relationship. In yet some other studies, there is no evidence of any significant relationship. The current study therefore is an attempt to contribute to the debate using data from the Nigerian Stock market.

\section{Methodology and Data}

The paper recognizes that in a dynamic stock market environment a number of factors are often responsible in explaining observed variability in stock prices. However, a single five- variable fiscal-stock price model patterned after multivariate regression, Granger causality and dynamic models of linear error correction mechanism have been constructed in this study. After the pre-estimation data analysis, the OLS, co-integration and causality test approaches adopted in this study presume that variability in stock prices could be explained by a set of four critical fiscal policy variables namely- PEX, DBT, NOR and MSP as defined in section 3.1 in which money supply MSP serves as a control variable to account for the monetary transmission path of fiscal policy as demonstrated by (Laopodis, 2006) that fiscal policy actions interact with monetary policy to affect stock prices. 


\subsection{Data and Test Variables}

The study employs aggregate data for stock prices and fiscal policy indicators for the period 1985-2012. Key data variables used in this study are Nigerian Stock Exchange All- Share index (ASI) representing stock prices, Federal Government total Public Expenditure (PEX) which is the sum of Capital Expenditure (CEX) and Recurrent Expenditure (REX), Non-Oil Revenue (NOR), Domestic Debt Outstanding (DBT) capturing fiscal policy measures and Broad Money Supply (MSP) as a control variable as earlier mentioned. The time series data were collected from the Central Bank of Nigeria Statistical Bulletin 2012 issue. Operationally, Government expenditure measures the aggregate of a country's public sector spending in all aspects of its activities while All Share index measures the average value or price of all the stocks quoted and traded on the stock exchange on a specific date. The aggregate data in respect of the selected variables are presented in Table 1 in the Appendixes.

\subsection{The Model}

Based on the theoretical underpinnings and empirical review earlier made in this paper, we hypothesize that stock price is a function of fiscal policy indicators. The relationship between fiscal policy indicators and stock prices is modelled as follows using the log transform of the variables.

$$
\log \left(\mathrm{ASI}_{\mathrm{t}}\right) \mathrm{a}_{\mathrm{o}}+\mathrm{a}_{1} \log \left(\mathrm{PEX}_{\mathrm{it}}\right)+\mathrm{a}_{2} \log \left(\mathrm{DBT}_{\mathrm{it}}\right)+\mathrm{a}_{3} \log \left(\mathrm{NOR}_{\mathrm{it}}\right)+\mathrm{a}_{4} \log \left(\mathrm{MSP}_{\mathrm{it}}\right)+\mathrm{U}_{\mathrm{t}}
$$

Where

$\begin{array}{ll}\text { ASI } & =\text { All Share Index } \\ \text { PEX } & =\text { Total Public Expenditure (N'Million) } \\ \text { DBT } & =\text { Domestic Debt Outstanding (N'Million) } \\ \text { NOR } & =\text { Non-Oil Revenue (N'Million) } \\ \text { MSP } & =\text { Broad Money Supply (N'Million) } \\ U_{t} & =\text { Error Term } \\ a_{0} & =\text { Intercept } \\ a_{1} \text { to } \mathrm{a}_{4} & =\text { Parameters }\left(\mathrm{a}_{1}, \mathrm{a}_{4}>0 \text { and } \mathrm{a}_{2}, \mathrm{a}_{3}<0\right) .\end{array}$

The framework for data analysis in this study starts with the pre-estimation technique of descriptive statistics and correlation matrix.

\section{Empirical Results and Analysis}

The empirical results and analyses of the application of our models are presented in this section beginning with the summary of the descriptive statistics of the selected variables in our model as depicted in equation (1).

\subsection{Descriptive Statistics}

Table 1. Summary descriptive statistics

\begin{tabular}{lccccc}
\hline \multicolumn{1}{c}{ ASI } & PEX & DBT & NOR & MSP \\
Mean & 12605.94 & 1189566. & 1364198. & 577603.9 & 2742218. \\
Median & 6716.300 & 594082.2 & 677818.4 & 195382.7 & 558549.0 \\
Maximum & 57990.20 & 4233013. & 6537536. & 2628771. & 13895389 \\
Minimum & 127.3000 & 13041.10 & 27949.10 & 4126.700 & 22299.24 \\
Std. Dev. & 14066.72 & 1387905. & 1740080. & 748340.9 & 4158726. \\
Skewness & 1.358283 & 1.114447 & 1.697483 & 1.383083 & 1.568004 \\
Kurtosis & 4.794278 & 2.916417 & 5.007114 & 3.847148 & 4.052613 \\
& & & & & \\
Jarque-Bera & 12.36569 & 5.804112 & 18.14669 & 9.764226 & 12.76630 \\
Probability & 0.002065 & 0.054910 & 0.000115 & 0.007581 & 0.001690 \\
Sum & & & & & \\
Sum Sq. Dev. & 552966.4 & 33307843 & 38197534 & 16172911 & 76782105 \\
Observations & $5.34 \mathrm{E}+09$ & $5.20 \mathrm{E}+13$ & $8.18 \mathrm{E}+13$ & $1.51 \mathrm{E}+13$ & $4.67 \mathrm{E}+14$ \\
\hline Source: Author & 28 & & & & 28 \\
\hline
\end{tabular}

Source: Author's computation 
The descriptive statistics for the variables are shown in Table 1. The mean value of All Share Index $\left(\operatorname{ASI}_{\mathrm{it}}\right)$ is 12605.94 with a median of 6716.3 while standard deviation is 14066.72 . The mean of Public Expenditure (PEX $\mathrm{X}_{\mathrm{it}}$ ) is N1189566.0 million and median is N594082.2millio with a standard deviation of N1387905.0 million. The mean value for Federal Government's total Domestic Debt Outstanding $\left(\mathrm{DBT}_{\mathrm{it}}\right)$ is $\mathrm{N} 1364198.0$ million with a median value of N677818.4 million and standard deviation of N1740080.0 million. For Federal Government Non-Oil Revenue $\left(\mathrm{NOR}_{\mathrm{it}}\right)$ the mean value is N577603.9 million with a median value of N195382.7 million and standard deviation of N748340.9 million, while the mean value of Broad Money Supply $\left(\mathrm{MSP}_{\mathrm{it}}\right)$ is N2742218.0 million with a median of N558549.0 million and standard deviation of N4158726.0 million.

\subsubsection{Normality Assumption for $\mathrm{u}_{\mathrm{i}}$}

The kurtosis of all the variables is greater than 3 except that of Government Public Expenditure (PEX). This shows that but for PEX which is platytokurtic in nature, the other variables in the series are leptokurtic in nature implying that they are with higher than normal kurtosis and the weight in the tail of their probability density function is larger than normal. That is, the coefficient of symmetry (skewness) of each variable is high (well above 1) for all the variables except for PEX that is marginally above 1. Again, the coefficient of flatness (kurtosis) for all the variables except PEX is above 3 which does not confirm normality. The Jarque-Bera test statistic also rejects the null hypothesis of normal distribution of each variable except for PEX. Thus, at 5\% level of significance, the probability values of the Jarque-Bera Statistic for the variables show that $\mathrm{ASI}_{\mathrm{it}}, \mathrm{DBT}_{\mathrm{it}}$ and $\mathrm{MSP}_{\mathrm{it}}$ are not normally distributed given that their $\mathrm{p}$-values are less than 0.05 but $\mathrm{PEX}_{\mathrm{it}}$ is normally distributed.

\subsubsection{Correlation Matrix}

Table 2. Summary correlation matrix

\begin{tabular}{cccccc}
\hline & ASI & DBT & MSP & NOR & PEX \\
ASI & 1.000000 & & & & \\
DBT & 0.678603 & 1.000000 & & & \\
MSP & 0.649475 & 0.975424 & 1.000000 & & \\
NOR & 0.696288 & 0.978595 & 0.978997 & 1.000000 & \\
PEX & 0.748211 & 0.962317 & 0.976866 & 0.977881 & 1.000000
\end{tabular}

Source: Author's Computation

Table 2 reports a correlation matrix between all pairs of variables in the model and indicate that All Share Index (ASI) positively correlates with DBT, MSP, NOR and PEX respectively. The correlation coefficients are all higher than 0.5 approximately, indicating that there seems to be strong correlation among the dependent and independent variables.

\subsection{Level Series Regression Analysis}

The multiple regression test results are shown in Table 3 and reveal that changes in Federal Government's total Public expenditure (PEX) positively and significantly impact on All share index (ASI). The other independent variables namely- Domestic Debt (DBT), Non-Oil Revenue (NOR) and Broad Money Supply (MSP) do not significantly impact on stock prices (ASI). The adjusted R2 of the estimated multiple regression model is 0.948811 indicating that the model explains approximately $94.88 \%$ of the total variation in ASI. In addition, the value of the F-statistic is 126.1143 with a p-value of 0.0000 suggesting the estimated model is a good fit.

However, the Durbin-Watson statistic is 0.803232 which indicates the presence of autocorrelation in the residuals thus rendering the estimated results unreliable for both analysis and policy making. Given the presence of autocorrelation, the ADF unit root test is employed to examine the time-dependent characteristics of the variables in our model. 
Table 3. Level series multiple regression test results

Dependent Variable: $\log (\mathrm{ASI})$

Method: Least Squares

Sample : 19852012

Included observations: 28

\begin{tabular}{lrlll}
\hline \multicolumn{1}{c}{ Variable } & Coefficient & Std. Error & t-Statistic & Prob. \\
\hline C & -4.859272 & 1.142596 & -4.252834 & 0.0003 \\
Log(PEX) & 0.904813 & 0.436894 & 2.071013 & 0.0498 \\
Log(DBT) & 0.288038 & 0.381907 & 0.754208 & 0.4584 \\
Log(NOR) & 0.259468 & 0.299680 & 0.865820 & 0.3955 \\
$\quad$ Log(MSP) & -0.400722 & 0.272869 & -1.468551 & 0.1555 \\
\hline R-squared & 0.956395 & Mean dependent var & 8.375903 \\
Adjusted R-squared & 0.948811 & S.D. dependent var & 1.888620 \\
S.E. of regression & 0.427300 & Akaike info criterion & 1.297772 \\
Sum squared resid & 4.199463 & Schwarz criterion & 1.535666 \\
Log likelihood & -13.16881 & Hannan-Quinn criter. & 1.370499 \\
F-statistic & 126.1143 & Durbin-Watson stat & 0.803232 \\
Prob(F-statistic) & 0.000000 & & \\
\hline
\end{tabular}

Authors' Computation

\subsection{Unit Root Test Results}

The summary of the ADF unit root test results of the variables in our model are presented in Table 4. The results show that all the variables except the residuals were stationary after the first differencing. This means that they are all integrated of order one while the residuals (ECM term) are integrated of order zero. at their levels..

Table 4. ADF unit root test results

\begin{tabular}{lll}
\hline Variable & $\begin{array}{l}\text { ADF test statistic at } \\
1^{\text {st }} \text { diff. }\end{array}$ & $\begin{array}{l}\text { Order } \\
\text { integration. }\end{array}$ \\
\hline $\log (\mathrm{ASI})$ & -3.766793 & $1(1)$ \\
\hline $\log (\mathrm{PEX})$ & -4.028248 & $1(1)$ \\
\hline $\log (\mathrm{DBT})$ & -4.865670 & $1(1)$ \\
\hline $\log (\mathrm{NOR})$ & -6.989215 & $1(1)$ \\
\hline $\log (\mathrm{MSP})$ & -4.022961 & $1(1)$ \\
\hline Residual $(\mathrm{ECM})$ & -5.350358 & $1(0)$ \\
\hline
\end{tabular}

Critical Values: $1 \%-3.766793,5 \%-2.981038,10 \%-2.629906$.

Source: Author's Computation.

\subsection{Co-integration Test}

The Johansen co-integration test results are as shown in Table 5. The test assumes linear deterministic trend in the variables with a lag of 1 to 1 . Both the Trace and the Maximum Eigenvalue statistics of the unrestricted co-integration rank tests indicate one co-integrating equations at the $5 \%$ level of significance. This therefore confirms the presence of one long run dynamic equilibrium relationship among the dependent and independent variables of our model. 
Table 5. Johansen co-integration test results

Sample (adjusted): 19872012

Included Observations: 26 after adjustments

Trend assumption: Linear deterministic trend

Series: $\log$ (ASI) $\log$ (PEX) $\log (\mathrm{DBT}) \log (\mathrm{NOR}) \log (\mathrm{MSP})$

Lags interval (in first differences): 1 to 1

Unrestricted Cointegration Rank Test (Trace)

\begin{tabular}{lllll}
\hline $\begin{array}{l}\text { Hypothesized } \\
\text { N0.of CE(s) }\end{array}$ & Eigenvalue & Trace & 0.05 & \\
None* & 0.834679 & 83.38994 & 69.81889 & 0.0028 \\
\hline At most 1 & 0.460409 & 36.59349 & 47.85613 & 0.3670 \\
\hline At most 2 & 0.296489 & 20.55295 & 29.79707 & 0.3861 \\
\hline At most 3 & 0.239352 & 11.40949 & 15.49471 & 0.1875 \\
\hline At most 4* & 0.152311 & 4.296284 & 3.841466 & 0.0382 \\
\hline
\end{tabular}

Trace test indicates 1 co-integrating eqn(s) at the 0.05 level

*denotes rejection of the hypothesis at the 0.05 level

**Mackinnon-Haug-Michelis (1999) P-values

Unrestricted Cointegration Rank Test (Maximum Eigenvalue)

\begin{tabular}{|c|c|c|c|c|}
\hline Hypothesized & & Max-Eigen & 0.05 & \\
\hline No. of CE(s) & Eignenvalue & Statistics & Critical Value & Prob** \\
\hline None* & 0.834679 & 46.79645 & 33.87687 & 0.0009 \\
\hline At most 1 & 0.460409 & 16.04054 & 27.58434 & 0.6623 \\
\hline At most 2 & 0.296489 & 9.143460 & 21.13162 & 0.8207 \\
\hline At most 3 & 0.239352 & 7.113207 & 14.26460 & 0.4759 \\
\hline At most $4^{*}$ & 0.152311 & 4.296284 & 3.841466 & 0.0382 \\
\hline $\begin{array}{l}\text { Max-eigenvalu } \\
* \text { denotes rejec } \\
* * \text { Mackinnon- }\end{array}$ & $\begin{array}{l}\text { ndicates } 1 \text { co-in } \\
\text { the hypothesis } \\
\text { Michelis (1999) }\end{array}$ & $\begin{array}{l}\text { ing eqn(s) at the } 0 \\
.05 \text { level } \\
\text { des }\end{array}$ & evel & \\
\hline
\end{tabular}

Source: Author's Computation.

\subsection{Error Correction Mechanism (ECM)}

Having established that there is one co-integrating long run equilibrium relationship among the variables in our model, the short run relationship was examined using error correction mechanism (ECM) within the framework of an Autoregressive Distributed Lag (ARDL) model. An ARDL model incorporates the lagged values of the independent variables among the set of explanatory variables (Gujarati and Porter, 2009).

The ECM corrects for equilibrium by incorporating both the short run and long run effects in a dynamic setting from where an over-parameterized ECM estimates and the corresponding parsimonious ECM results are obtained. The parsimonious ECM estimates are derived by successively deleting insignificant variables from the over-parameterized ECM model until an optimum parsimonious ECM model estimate is achieved (Ogbulu and Uruakpa, 2011).

Table 6 presents the results of the estimated parsimonious ECM which incorporates three-lagged values of the explanatory variables and one-period lagged value of the error term ECM. The results of the estimated over-parameterized ECM are however presented in Appendix 1 in the Appendixes. 
Table 6. Parsimonious error correction model results

\begin{tabular}{|c|c|c|c|c|}
\hline \multicolumn{5}{|c|}{$\begin{array}{l}\text { Method: Least Squares } \\
\text { Sample (adjusted): } 19892012 \\
\text { Included Observations: } 24 \text { after adjustı }\end{array}$} \\
\hline Variable & Coefficient & Std. Error & t-Statistic & Prob. \\
\hline $\mathrm{C}$ & 0.395865 & 0.167590 & 2.362096 & 0.0646 \\
\hline$\overline{\mathrm{D}(\log (\mathrm{ASI}(-1)))}$ & 0.651799 & 0.127532 & 5.110882 & 0.0037 \\
\hline $\mathrm{D}(\log (\operatorname{ASI}(-2)))$ & 0.829911 & 0.164380 & 5.048733 & 0.0039 \\
\hline $\mathrm{D}(\log (\mathrm{ASI}(-3)))$ & 1.459592 & 0.204762 & 7.128221 & 0.0008 \\
\hline $\mathrm{D}(\log (\mathrm{PEX}))$ & -0.706960 & 0.194685 & -3.631309 & 0.0150 \\
\hline $\mathrm{D}(\log (\operatorname{PEX}(-1)))$ & -1.857787 & 0.251516 & -7.386364 & 0.0007 \\
\hline $\mathrm{D}(\log (\operatorname{PEX}(-2)))$ & -3.151661 & 0.453015 & -6.957075 & 0.0009 \\
\hline $\mathrm{D}(\log (\operatorname{PEX}(-3)))$ & -1.073753 & 0.324284 & -3.311146 & 0.0212 \\
\hline $\mathrm{D}(\log (\mathrm{DBT}))$ & 0.611041 & 0.168931 & 3.617095 & 0.0153 \\
\hline $\mathrm{D}(\log (\mathrm{DBT}(-1)))$ & 1.204235 & 0.250383 & 4.809568 & 0.0048 \\
\hline $\mathrm{D}(\log (\mathrm{DBT}(-2)))$ & -0.361776 & 0.265552 & -1.362350 & 0.2312 \\
\hline $\mathrm{D}(\log (\mathrm{NOR}))$ & 1.531044 & 0.207135 & 7.391532 & 0.0007 \\
\hline $\mathrm{D}(\log (\operatorname{NOR}(-1)))$ & 0.416673 & 0.153168 & 2.720362 & 0.0418 \\
\hline $\mathrm{D}(\log (\operatorname{NOR}(-2)))$ & 0.194479 & 0.090475 & 2.149539 & 0.0843 \\
\hline $\mathrm{D}(\log (\mathrm{MSP}))$ & 0.631903 & 0.438641 & 1.440593 & 0.2093 \\
\hline $\mathrm{D}(\log (\mathrm{MSP}(-1)))$ & -0.739175 & 0.395914 & -1.867011 & 0.1209 \\
\hline $\mathrm{D}(\log (\operatorname{MSP}(-2)))$ & -1.300326 & 0.406009 & -3.202699 & 0.0239 \\
\hline $\mathrm{D}(\log (\operatorname{MSP}(-3)))$ & 1.109938 & 0.398901 & 2.782492 & 0.0388 \\
\hline ECM01(-1) & -1.022758 & 0.131245 & -7.792718 & 0.0006 \\
\hline R-squared & 0.972632 & Mean Dependent Var & 0.199548 & \\
\hline Adjusted R-squared & 0.874108 & S.D. dependent Var & 0.323842 & \\
\hline S.E of regression & 0.114903 & Akaike info criterion & -1.474742 & \\
\hline Sum squared resid & 0.066013 & Schwarz criterion & -0.542116 & \\
\hline Log likelihood & 36.69690 & F-statistic & 9.972053 & \\
\hline Durbin-Watson Stat & 2.053176 & Prob(F-statistic) & 0.009405 & \\
\hline
\end{tabular}

Source: Author's Computation

From Table 6, the estimated results of the parsimonious ECM show that Federal Government's Public Expenditure (PEX) has a negative and significant relationship with stock prices (ASI). In addition, all the lagged values of PEX are negatively and significantly related to ASI at the $5 \%$ level of significance. The results also indicate that Domestic Debt Outstanding (DBT) has a positive and significant impact on ASI. The one-period lagged value of PEX also impacts positively and significantly on stock prices (ASI). The two-period lagged value of PEX however is not significantly related to ASI. Furthermore, Non-Oil Revenue (NOR) exhibits a positive and significant relationship with (ASI) just as (NOR) lagged one-period impacts positively and significantly on ASI. The empirical results also show that Broad Money Supply (MSP) does not appear to have a significant influence on stock prices (ASI). However, both the two-period and three-period lagged values of MSP do significantly influence stock prices.

The adjusted $\mathrm{R}^{2}$ of the model is approximately $87.41 \%$ indicating that the explanatory variables jointly explain $87.41 \%$ of the total variations in stock prices (ASI). The F-statistic is significant at a value of 9.872053 and a p-value of 0.009405 which shows that the model is a good fit. The Durbin-Watson statistic value is approximately 2.05 and confirms the absence of any autocorrelation in the ECM model. Thus, the ECM model results presented in Table 6 are obviously better than the level series multiple regression results in Table 3.

The error correction term with a coefficient value of -1.022758 is significant and appropriately signed. The ECM value provides an insight with regards to the speed of adjustment of the model from its long run equilibrium in response to any short run shock. The ECM value of -1.022758 therefore indicates that a short-run disequilibrium in the fiscal policy-stock price model will be corrected at a speed of $2.28 \%$ per annum.

\subsection{Granger Causality Test}

Granger causality test is employed to test for the direction of causality between the fiscal policy variables and stock prices in our model. In Table 7 we present the results of the Pairwise Granger causality test conducted with a maximum lag of 2. The empirical results show that there is a uni-directional causality running from stock prices (ASI) to Public Expenditure (PEX), Domestic Debt (DBT) and Broad Money Supply (MSP) respectively. On the other hand, a uni-directional causality from Non-Oil Revenue (NOR) to stock prices (ASI) is observed. 
The causality results show that stock market prices (ASI) granger causes PEX, which indicates that changes in stock market prices lead changes in public expenditure (PEX). This further confirms that ASI and PEX do not only correlate strongly as shown in the correlation matrix in Table 2, but adjustments in stock prices lead changes in Federal Government Public Expenditure. In addition, ASI Granger causes DBT implying that changes in stock prices in the Nigerian stock market lead changes in domestic borrowing to finance government budget deficits.

Table 7. Pairwise Granger Causality Test

Sample: 19852012

Lags: 2

\begin{tabular}{lccr}
\hline Null Hypothesis: & Obs & F-Statistic & Prob. \\
\hline PEX does not Granger Cause ASI & 26 & 1.73689 & 0.2004 \\
ASI does not Granger Cause PEX & & 11.7475 & $0.0004^{*}$ \\
\hline DBT does not Granger Cause ASI & 26 & 1.04822 & 0.3682 \\
ASI does not Granger Cause DBT & & 18.5930 & $2 . \mathrm{E}-05^{*}$ \\
\hline MSP does not Granger Cause ASI & 26 & 0.78215 & 0.4703 \\
ASI does not Granger Cause MSP & & 26.8280 & $2 . \mathrm{E}-06^{*}$ \\
\hline NOR does not Granger Cause ASI & 26 & 3.60608 & $0.0451^{*}$ \\
ASI does not Granger Cause NOR & & 0.64926 & 0.5326 \\
\hline
\end{tabular}

*Significant at $5 \%$.

ASI does not Granger Cause NOR

Source: Author's Computation.

\subsection{Impulse Response and Variance Decomposition Analysis}

To examine the response of the dependent variable in a Vector Autoregressive (VAR) model to shocks or innovations in the error terms, the Impulse Response Function (IRF) and the Variance Decomposition (VDC) are employed in this paper. The two techniques help us to trace the response of Stock Prices (ASI), the dependent variable in our fiscal policy-stock price model, to shocks in the error terms for several periods in the future (Gujarati and Porter, 2009). The empirical results of the application of the IRF and VDC analysis to our model are as shown in Tables 8 and 9 .

Table 8. Impulse response function estimates

\begin{tabular}{|c|c|c|c|c|c|}
\hline \multicolumn{6}{|c|}{ Response of $\log (\mathrm{ASI})$ : } \\
\hline Period & $\log (\mathrm{ASI})$ & $\log (\mathrm{PEX})$ & $\log (\mathrm{DBT})$ & $\log (\mathrm{NOR})$ & $\log (\mathrm{MSP})$ \\
\hline \multirow[t]{2}{*}{1} & 0.296016 & 0.000000 & 0.000000 & 0.000000 & 0.000000 \\
\hline & $(0.04105)$ & $(0.00000)$ & $(0.00000)$ & $(0.00000)$ & $(0.00000)$ \\
\hline \multirow[t]{2}{*}{2} & 0.297286 & 0.041416 & 0.040865 & -0.017428 & -0.005077 \\
\hline & $(0.08368)$ & $(0.06770)$ & $(0.07151)$ & $(0.04278)$ & $(0.05734)$ \\
\hline \multirow[t]{2}{*}{3} & 0.162905 & 0.161298 & 0.042735 & -0.012327 & -0.027435 \\
\hline & $(0.10607)$ & $(0.08084)$ & $(0.09973)$ & $(0.05382)$ & $(0.07546)$ \\
\hline \multirow[t]{2}{*}{4} & 0.077607 & 0.135395 & 0.020018 & 0.012413 & -0.046002 \\
\hline & $(0.12099)$ & $(0.08281)$ & $(0.11736)$ & $(0.05115)$ & $(0.07419)$ \\
\hline \multirow[t]{2}{*}{5} & 0.068169 & 0.116675 & -0.000267 & 0.017439 & -0.055027 \\
\hline & $(0.13542)$ & $(0.06933)$ & $(0.11901)$ & $(0.03741)$ & $(0.06892)$ \\
\hline \multirow[t]{2}{*}{6} & 0.079333 & 0.101557 & 0.016026 & 0.013099 & -0.059843 \\
\hline & $(0.13777)$ & $(0.06379)$ & $(0.11121)$ & $(0.03093)$ & $(0.07034)$ \\
\hline \multirow[t]{2}{*}{7} & 0.073234 & 0.109213 & 0.039783 & 0.007865 & -0.058827 \\
\hline & $(0.12771)$ & $(0.05816)$ & $(0.10324)$ & $(0.02985)$ & $(0.07216)$ \\
\hline \multirow[t]{2}{*}{8} & 0.057118 & 0.106121 & 0.057008 & 0.008466 & -0.054393 \\
\hline & $(0.11593)$ & $(0.06019)$ & $(0.09777)$ & $(0.03083)$ & $(0.07591)$ \\
\hline \multirow[t]{2}{*}{9} & 0.041992 & 0.100328 & 0.061995 & 0.008968 & -0.047745 \\
\hline & $(0.10864)$ & $(0.06057)$ & $(0.09376)$ & $(0.03041)$ & $(0.07897)$ \\
\hline \multirow[t]{2}{*}{10} & 0.031042 & 0,092505 & 0.063055 & 0.008225 & -0.041422 \\
\hline & $(0.10472)$ & $(0.05876)$ & $(0.09019)$ & $(0.02882)$ & $(0.08051)$ \\
\hline
\end{tabular}

Cholesky Ordering: $\log (\mathrm{ASI}) \log (\mathrm{PEX}) \log (\mathrm{DBT}) \log (\mathrm{NOR}) \log (\mathrm{MSP})$.

Source: Author's Computation. 
In Table 8, we present the results of the IRF estimates to one standard deviation innovations in each of the variables $\log (\mathrm{ASI}), \log (\mathrm{PEX}), \log (\mathrm{DBT}), \log (\mathrm{NOR})$ and $\log (\mathrm{MSP})$ in the VAR system for a period of ten(10) years into the future. The figures in parenthesis are the standard errors of the estimates and the Cholesky ordering is Log $(\mathrm{ASI}) \rightarrow \log (\mathrm{PEX}) \rightarrow \log (\mathrm{DBT}) \rightarrow \log (\mathrm{NOR}) \rightarrow \log (\mathrm{MSP})$. From Table 8, it is observed that the impulse response of Stock Prices (ASI) to own shocks is positive all through the 10-year forecast period ranging from a positive $29.6 \%$ in the first year to $29.73 \%$ in the $2^{\text {nd }}$ year before declining to $3.10 \%$ in the $10^{\text {th }}$ year. Continuing, the impulse response of stock prices (ASI) to shocks emanating from the other variables PEX, DBT, NOR and MSP in the $1^{\text {st }}$ year is zero. However, in the $2^{\text {nd }}$ year, the impulse responses are approximately $4.14 \%, 4.09 \%,-1.74 \%$ and $-0.51 \%$ respectively and in the $10^{\text {th }}$ year, the impulse responses are $9.25 \%, 6.31 \%, 0.82 \%$ and $-4.14 \%$ respectively. It is also observed that the impulse response of ASI to shocks from MSP are all negative from the $2^{\text {nd }}$ year through to the $10^{\text {th }}$ year.

Table 9. Variance decomposition estimates

\begin{tabular}{|c|c|c|c|c|c|c|}
\hline \multicolumn{7}{|c|}{ Variance Decomposition of $\log (\mathrm{ASI})$ : } \\
\hline Period & S.E & $\log (\mathrm{ASI})$ & $\log (\mathrm{PEX})$ & $\log (\mathrm{DBT})$ & $\log (\mathrm{NOR})$ & $\log (\mathrm{MSP})$ \\
\hline 1 & 0.296016 & 100.0000 & 0.000000 & 0.000000 & 0.000000 & 0.000000 \\
\hline 2 & 0.423933 & 97.93302 & 0.954411 & 0.929218 & 0.169006 & 0.014342 \\
\hline 3 & 0.484773 & 86.18636 & 11.80074 & 1.487734 & 0.193908 & 0.331260 \\
\hline 4 & 0.511889 & 79.59568 & 17.57969 & 1.487218 & 0.232714 & 1.104700 \\
\hline 5 & 0.532563 & 75.17448 & 21.04106 & 1.374021 & 0.322225 & 2.088212 \\
\hline 6 & 0.551580 & 72.14887 & 23.00522 & 1.365323 & 0.356789 & 3.123804 \\
\hline 7 & 0.571521 & 68.84389 & 25.07949 & 1.756242 & 0.351263 & 3.969100 \\
\hline 8 & 0.589441 & 65.66059 & 26.81911 & 2.586469 & 0.350859 & 4.582977 \\
\hline 9 & 0.604543 & 62.90336 & 28.25003 & 3.510478 & 0.355555 & 4.980586 \\
\hline 10 & 0.617052 & 60.63204 & 29.36375 & 4.413822 & 0.359052 & 5.231342 \\
\hline
\end{tabular}

Cholesky Ordering: Log (ASI) $\log (\mathrm{PEX}) \log (\mathrm{DBT}) \log (\mathrm{NOR}) \log (\mathrm{MSP})$.

Source: Author's Computation

The results presented in Table 9 show the variance decomposition of the five variables in our fiscal policy-stock price model estimated also for a 10-year forecast period into the future. As with the IRF, the Variance Decomposition analysis helps us to determine the total proportion of forecast error attributable to own shocks and to shocks in the other variables in a model (Ogbulu, 2012).

The results show that own shocks represent the dominant source of variation in the forecast errors of the variables. For example, the variance decomposition of stock prices Log (ASI) shows that own shocks constitute $100 \%$ in the $1^{\text {st }}$ year with the other variables contributing nothing $(0 \%)$. However, from the $2^{\text {nd }}$ year, own shocks gradually and steadily reduce from $97.93 \%$ in that year to $72.15 \%$ in the $6^{\text {th }}$ year and $60.63 \%$ in the $10^{\text {th }}$ year while the other variables PEX, DBT, NOR and MSP account for $29.36 \%, 4.41 \%, 0.36 \%$ and $5.23 \%$ respectively in the $10^{\text {th }}$ year.

\section{Summary and Discussion of Findings}

Broadly speaking, this paper set out to assess the extent to which government fiscal actions impact on stock market prices in the capital market. Given the fiscal policy-stock price model estimated in the study, we present here the summary and discussion of our findings.

It is observed that all the variables in our model are integrated of order one 1(1) using the ADF unit root test. That is, they become stationary after the first differencing.

The Johansen co-integration test conducted in both the trace and the maximum eigenvalue tests report the existence of one co-integration equation among the variables at the $5 \%$ level of significance and using a lag interval of 1 to 1 . This indicates that there is only one long run equilibrium relationship among the dependent and independent variables in our fiscal policy-stock price model.

The results of the parsimonious ECM depicted in Table 6 report a significant but negative relationship between Public Expenditure (PEX) and stock prices (ASI) for both the current and lagged values of PEX. This shows that changes in Government total public expenditure have the potential of impacting significantly on the stock market and this finding agrees with the results of earlier works of Darrat (1988), Laopodis (2006), DeLeeuw and Holloway (1985) as well as Hoelscher (1986). However, the observed negative relationship between PEX and ASI is in contrast with our apriori expectation but has empirical support in the works of Lee (1997) and Barnhart and Darrat (1989). 
Our empirical results also indicate that Domestic Debt Outstanding (DBT) has a positive and significant relationship with stock prices (ASI) although the positive relationship is not in conformity with theoretical expectation. An increase in government borrowing (say through the issuance of government securities) to finance its fiscal operations, raises interest rates in the market which in turn lower the discounted cash flows from stocks and thus stock prices (Patelis, 1991; Travares and Valkanov, 2003; Laopodis, 2010).

Furthermore, Non-Oil Revenue (NOR) has a positive and significant relationship with Stock Prices (ASI) for both the current and lagged values of the variable. Once again, the observed positive sign is contrary to our apriori expectation. Given that Non-Oil Revenue is derived from sundry taxes (VAT inclusive), duties, tariffs and levies on consumption and production by different economic units in the economy, an increase in Non-Oil Revenue reduces after-tax cash flows on financial assets thus reducing their market prices.

The observed relationship between Money Supply (MSP) and ASI in the current period is positive in line with apriori expectation but not significant. However, the two-period and three-period lagged values of MSP are significant indicating that money supply has a lagged effect on stock prices.

Overall, the reported F-statistic in the parsimonious ECM results is significant indicating that there is a significant relationship between fiscal policy variables and stock prices in the Nigerian capital market. Thus, we reject the null hypothesis that there is no significant relationship between fiscal policy and stock prices in Nigeria. The observed deviation of the signs of some of the parameter co-efficients in the estimated parsimonious ECM model could be due to the structure of the Nigerian capital market which is largely informationally inefficient such that the market may not always react timely and correctly to fiscal policy stimuli emanating from government fiscal actions.

The results of the Granger causality test vividly demonstrate that the null hypothesis of no Granger causality relationship between fiscal policy variables and stock prices cannot be accepted given the observed unidirectional granger causality from ASI to PEX, DBT and MSP respectively and unidirectional causality from NOR to ASI. These results are in consonance with the empirical findings of (Rogalski and Vinso, 1977), Levine (1991) and Lee (1997).

Extending our analysis to the examination of the IRF and VDC of the fiscal policy-stock price relationship shows that the impulse response of ASI to own shocks is positive all through the 10-year forecast period just as own shocks represent the dominant source of forecast error in the variance decomposition analysis.

\section{Conclusion}

This paper set out to investigate the nature of the relationship between fiscal policy measures and stock prices in the Nigerian capital market during the period $1985-2012$ as well as examining the direction of their relationship. The application of the parsimonious ECM reports a significant relationship between fiscal policy variables and stock prices in the Nigerian capital market. In addition, the results also show that the two-period lagged broad money supply, as a control variable in the model, exerts a significant influence on stock prices. The empirical findings vividly demonstrate that changes in government fiscal actions through the instrumentality of changes in public expenditure, taxes and government borrowing would have profound impact on stock market prices. It is therefore recommended that policy makers should design and implement appropriate fiscal policies given their potential impact on the activities in the capital market.

\section{References}

Afful, K. B., \& Asiedu, K. F. (2013). Fiscal policy, interest rate spreads and stock markets in Sub-Saharan Africa. Business and Economics Journal, 2013, BEJ-81, 1-11.

Afonso, A., \& Sousa, R. M. (2008). The macroeconomic effects of fiscal policy. ECB Working Paper.

Anyanwu, J. C. (1997). Nigeria Public Finance. Onistha, Joanee Educational Publishers Ltd.

Barnhart, S. W., \& Darrat, A. F. (1989). Federal deficits and money growth in the United States. Journal of Banking and Finance, 13, 137-149.http://dx.doi.org/10.1016/0378-4266(89)90024-1

Chen, N., Roll, R., \& Ross, S. A. (1986). Economic forces and the stock market. Journal of Business, 59, 529-403. http://dx.doi.org/10.1086/296344

Da, Z., Warachta, M., \& Yun, H. (2012). The impact of fiscal policy on stock returns. Research Gate. http://dx.doi.org/10.2139/ssm.2020907

Darrat, A. F. (1988). On fiscal policy and the stock market. Journal of Money, Credit and Banking, 20(3), 353-363. http://dx.doi.org/10.2307/1992261

DeLeeuw, F., \& Holloway, T. M. (1985). The measurement and significance of the cyclically-adjusted Federal budget and debt. Journal of Money, Credit and Banking, 17(2), 232-242. http://dx.doi.org/10.2307/1992336 
Desai, A., Wright, P., \& Chung, K. (2003). Impact of changes in strategic investment on shareholder returns: the role of growth opportunities. Journal of Applied Business Research, 19, 41-56.

Ezirim, C. B. (2005). Finance Dynamics. Port Harcourt, Markowitz Centre for Research \& Development.

Ezirim, C. B., Muohgalu, M. I., Elike, U., \& Amuzie, A. E. (2010). Public expenditure growth, inflation and cointegration: evidence from Nigeria. International Journal of Business and Behavioural Sciences' Research, 1(1), 1-14.

Fatas, A., \& Mihov, I. (2001). The effects of fiscal policy on consumption and employment: theory and evidence, CEPR, Working Paper, No. 2760.

Gujarati, D. N., \& Porter, D. C. (2009). Basic Econometrics (5 ${ }^{\text {th }}$ ed.). New York, McGraw-Hill/Irwin Inc.

Hebous, S., \& Zimmermann, T. (2013). Estimating the effects of co-ordinated fiscal actions in the Euro Area. European Economic Review, 58, 110-121. http://dx.doi.org/10.1016/j.euroecorev.2012.12.002

Hoelscher, G. (1986). New evidence on deficits and interest rates. Journal of Money, Credit and Banking, 18, 1-17. http://dx.doi.org/10.2307/1992316

Hsing, Y. (2013). Effects of fiscal policy and monetary policy on the stock market in Poland. Economies, 1, 19-25. http://dx.doi.org/10.3390/economies 1030019

Laopodis, N. T. (2009). Fiscal policy and stock market efficiency: evidence for the United States. The Quarterly Review of Economics and Finance, 49(2), 633-650. http://dx.doi.org/10.1016/j.gref.2007.10.004

Laopodis, N. T. (2010). Dynamic linkages between monetary policy and stock market. Review of Quantitative Finance and Accounting, 35, 271-293. http://dx.doi.org/10.1007/s11156-009-0154-7

Lee, U. (1997). Stock markets and macroeconomic policies: new evidence from Pacific Basin Countries. Multinational Finance Journal, 1, 273-289.

Lee, U. (2007). Stock returns and fiscal policy: additional international evidence. Indian Journal of Economics and Business, 6(2), 241-256.

Leeper, E., \& Yun, T. (2006). Monetary-fiscal policy interactions and the price level: background and beyond. International Tax and Public Finance, 13(4), 373-409. http://dx.doi.org/10.1007/s10797-006-8599-2

Levine, R. (1991). Stock markets, growth, and tax policy. The Journal of Finance, 46, 1445-1459. http://dx.doi.org/10.1111/j.1540-6261.1991.tb04625.x

McGrattan, E. R., \& Prescott, E. C. (2001). Tax, regulations and asset prices. Federal Reserve Bank of Minneapolis, Research Department, Working Paper 610.

Meek, T. (1960). The revival of international capital markets. American Economic Review, 50, 282-293.

Ogbulu, O. M., \& Uruakpa, P. C. (2011). Monetary policy and stock prices in Nigeria: a cointegration and error correction approach. ABSU Journal of Arts, Management, Education, Law and Social Sciences (JAMELSS), $1(1), 60-85$.

Ogbulu, O., \& Torbira, L. L. (2012, November). Monetary policy and the transmission mechanism: evidence from Nigeria. International Journal of Economics and Finance, 4(11), 122-133. http://dx.doi.org/10.5539/ijef.v4n11p122

Okafor, F. O. (1983). Investment decisions: evaluation of projects and securities. London, Cassell Publishers.

Patelis, A. D. (1991). Stock return predictability and the role of monetary policy. Journal of Finance, 52(5), 1951-1972. http://dx.doi.org/10.1111/j.1540-6261.1997.tb02747.x

Plosser, C. (1982). Government financing decisions and asset returns. Journal of Monetary Economics, 9, 325-352. http://dx.doi.org/10.1016/0304-3932(82)90022-8

Rad, A. A. (2003). The effect of inflation on government revenue and expenditure: the case of the Islamic Republic of Iran. OPEC Review, 27(4), 331-341. http://dx.doi.org/10.1111/j.0277-0180.2003.00074.x

Razin, A. (1987). Fiscal policies and the stock markets: international dimensions. Working Paper Series, No.2389, National Bereau of Economic Research, September.

Reilly, F. R., \& Norton, E. A. (1999). Investments (5 ${ }^{\text {th }}$ ed.). New York, Harcourt Brace College Publishers.

Rogalski, R., \& Vinso, J. (1977). Stock returns, money supply and the direction of causality. Journal of Finance, 32, 1017-1030. http://dx.doi.org/10.1111/j.1540-6261.1977.tb03306.x

Tavares, J., \& Valkanov, R. (2003). Fiscal policy and asset returns. Working Paper, pp. 1-54. 